\title{
17 $\beta$-Hydroxysteroid dehydrogenases involved in local oestrogen synthesis have prognostic significance in breast cancer
}

\author{
C Gunnarsson*,', E Hellqvist,' O Stål' and the Southeast Sweden Breast Cancer Group ${ }^{2}$ \\ 'Department of Biomedicine and Surgery, Division of Oncology, Faculty of Health Sciences, Linköping, Sweden
}

The 17 3 -hydroxysteroid dehydrogenase (I7HSD) enzymes are involved in the local regulation of sex steroids. The I7HSD type I enzyme catalyses the interconversion of the weak oestrone (EI) to the more potent oestradiol (E2), whereas I7HSD type 2 catalyses the oxidation of E2 to El. The aim of this study was to correlate the expression of these enzymes in the tumour with the recurrence-free survival of tamoxifen-treated breast cancer patients. We used real-time reverse transcriptase PCR to investigate the mRNA expression of I7HSD types I and 2 in tumour samples from 230 postmenopausal patients. For the patients with oestrogen receptor (ER)-positive breast cancer, we found a statistically significant positive correlation between recurrence-free survival and expression of I7HSD type $2(P=0.026)$. We examined the ratio of I 7HSD types 2 and I, and ER-positive patients with low ratios showed a significantly higher rate of recurrence than those with higher ratios $(P=0.0047)$. ER positive patients with high expression levels of I 7HSD type I had a significantly higher risk for late relapse $(P=0.005 \mathrm{I})$. The expression of I 7HSD types I and 2 in breast cancer differs from the expression of these enzymes in normal mammary gland, and this study indicates that the expression has prognostic significance in breast cancer.

British Journal of Cancer (2005) 92, 547-552. doi:I0.1038/sj.bjc.6602375 www.bjcancer.com

Published online I February 2005

(c) 2005 Cancer Research UK

Keywords: $17 \beta$-hydroxysteroid dehydrogenase; breast cancer; oestradiol; real-time PCR; tamoxifen

Oestrogens play an important role in the development of hormone-dependent breast cancer. In premenopausal women, the majority of oestrogen is produced in the ovaries. In postmenopausal women, local oestrogens in breast carcinoma tissue originate through two main pathways, one involving aromatase, which converts androgens to oestrogens, and the other utilising steroid sulphatase, which converts oestrone sulphate into oestrone. $17 \beta$-Hydroxysteroid dehydrogenase (17HSD) activity is finally needed for the oestradiol/ oestrone regulation.

The 17HSD type 1 enzyme uses NADPH as a cofactor and catalyses the interconversion of the weak oestrogen, oestrone (E1), to the biologically more potent oestradiol (E2). 17 $\beta$-Hydroxysteroid dehydrogenase type 2 uses NAD + as a cofactor and catalyses the oxidation of testosterone and oestradiol to form androstendione and oestrone, respectively (Miettinen et al, 1996; Vihko et al, 2001). Previous studies have reported the presence of multiple 17HSD isoenzymes in humans, including type 3 and 4 (Speirs et al, 1998, 1999; Peltoketo et al, 1999), although types 1 and 2 seem to be the principal enzymes involved in reductive and oxidative

\footnotetext{
*Correspondence: Dr C Gunnarsson, Department of Oncology, University Hospital, Linköping SE-58I 85, Sweden;

E-mail: cecilia.gunnarsson@lio.se

${ }^{2}$ Members of the Southeast Sweden Breast Cancer Group: L-G Arnesson, B Nordenskjöld, K Nordenskjöld, Malmström A (Linköping), Bång H (Motala), A-C Källström (Norrköping), E Einarsson (Eksjö), B Norberg (Jönköping), P Skoog (Värnamo), M Sundquist (Kalmar), G Tejler (Västervik)

Received 16 August 2004; revised I December 2004; accepted 9 December 2004; published online I February 2005
}

activity in breast cancer, respectively (Miettinen et al, 1999). Moreover, previous studies have suggested that oestradiol can be produced in the same organ where it exerts its biological response. This is in agreement with the fact that breast cancer tissue possesses all the enzymes necessary for the bioformation of oestradiol (Yue et al, 1998; Purohit et al, 2002).

A few immunohistochemical studies of 17HSD type 1 in human breast cancer have been reported, suggesting that 17HSD type 1 may play an important role in the in situ regulation of oestradiol production in hormone-dependent breast carcinomas (Poutanen et al, 1992; Sasano et al, 1996; Suzuki et al, 2000). In a previous study, we found that the expression of both 17HSD types 1 and 2 differ in the tumours of patients with and without late relapse in the disease (Gunnarsson et al, 2001).

Oestrogen receptor (ER)-positive breast cancer is usually treated with tamoxifen, and long-term adjuvant tamoxifen is beneficial compared with treatment of shorter duration (Swedish Breast Cancer Cooperative Group, 1996). We hypothesised that the expression levels of 17HSD types 1 and 2, by affecting intratumoural oestradiol levels, might influence the response to endocrine treatment of breast cancer. The purpose of this study was to analyse the prognostic significance of 17HSD types 1 and 2 expression in a series of postmenopausal patients treated with adjuvant tamoxifen.

\section{MATERIAL AND METHODS}

We analysed frozen tissue from excised primary breast tumours of 230 women treated in the health-care region of southeast Sweden between 1985 and 1991. The patients were participants in a 
randomised multicentric trial where 2 and 5 years of adjuvant postoperative tamoxifen treatment was compared for postmenopausal patients less than 75 years of age (Swedish Breast Cancer Cooperative group). The daily dose of tamoxifen was $40 \mathrm{mg}$. All patients had primary breast cancer, stage II (UICC), without distant metastasis at the time of diagnosis. The median period of follow-up was 13.9 years. Primary surgery consisted of either modified radical mastectomy or breast-conserving surgery combined with axillary lymph node dissection. Radiotherapy (50 Gy) to the breast was offered to all patients treated with breast-conserving surgery. Lymph node-positive patients were treated with radiation directed to the breast/chest wall and regional lymph nodes. After surgery, the tumour samples were stored in a freezer $\left(-70^{\circ} \mathrm{C}\right)$ until RNA extraction was performed. Oestrogen receptor and progesterone receptor $(\mathrm{PgR})$ content was measured in clinical routine practice with isoelectric focusing before 1988 and thereafter with enzyme immunoassays (EIA) (Abbott Laboratories, Chicago, IL, USA). Samples with concentrations $\geqslant 0.1 \mathrm{fmol} \mu \mathrm{g}^{-1}$ DNA (or $\geqslant 0.3 \mathrm{fmol} \mu \mathrm{g}^{-1}$ DNA with EIA) were classified as positive. The present material is a subset of the patients in the region who participated in the trial, and includes the patients for whom frozen tumour samples were available after hormone receptor analysis. The characteristics of the tumours were similar to those in the complete series as regards a positive lymph node status (71 vs $74 \%)$, tumour size larger than $20 \mathrm{~mm}(69 \mathrm{vs} 60 \%)$ and a positive ER status (78 vs $76 \%)$. The study was approved by the regional ethics committee at Linköping University.

\section{RNA extraction}

Frozen breast tumour tissue $(30 \mathrm{mg})$ was homogenised in a microdismembrator (B Braun, Melsungen, Germany), and total RNA was extracted with the SV total RNA isolation system (Promega, Madison, WI, USA). The purified RNA was stored at $-70^{\circ} \mathrm{C}$, and the RNA content was determined by spectrophotometry. We also examined the expression of 17HSD types 1 and 2 in normal mammary gland. Total RNA from a pool of human breast tissue samples from 3 women (age 46-54 years) was purchased from ADH diagnostics (Life Technologies, Inc.).

\section{cDNA synthesis}

Total RNA (500 ng) was reverse-transcribed in a final volume of $20 \mu \mathrm{l}$, using Gibko BRL kit (Life Technologies, Inc., Stockholm, Sweden) with the following concentrations: $1 \times$ PCR buffer, $5 \mathrm{~mm}$ $\mathrm{MgCl}_{2}, 0.5 \mathrm{~mm}$ deoxynucleotide triphosphates, $2.5 \mu \mathrm{M}$ random hexamers, $10 \mathrm{~mm}$ DTT, and $0.5 \mu \mathrm{l}$ of Superscript reverse transcriptase (Life Technologies, Inc.) The thermal conditions used were as follows: $20^{\circ} \mathrm{C}$ for $10 \mathrm{~min}, 42^{\circ} \mathrm{C}$ for $50 \mathrm{~min}, 99^{\circ} \mathrm{C}$ for $5 \mathrm{~min}$, and after that $5^{\circ} \mathrm{C}$. The samples were stored at $4^{\circ} \mathrm{C}$ as the real-time PCR analysis was performed during the same day.

\section{Primers and probes}

We used the computer software Primer Express (PE Applied Biosystems, Foster City, CA, USA) to design primers and probes that recognised human $17 \beta$-HSD types 1 and 2 cDNA sequences. We conducted Blast searches (GenBank) to confirm the specificity of nucleotide sequences chosen for the primers and probes and the absence of DNA polymorphism. To avoid detection of contaminating genomic DNA, the probe was placed in the junction between two exons. The primer and probe sequences were; 17HSD type 1: forward primer: 5'-TAT GCG AGA GTC TGG CGG TT-3', reverse primer: $5^{\prime}-\mathrm{TGC}$ ACT GGG CCG CAC T-3', probe: $5^{\prime}$-CGA TCA GGC TCA AGT GGA CCC CAA-3'; 17HSD type 2: forward primer: 5'-TTA CCT GTG GAT CAG AAG GCA GT-3', reverse primer: $5^{\prime}$-TTG CAC AAA GCA TGG CCA-3', probe: $5^{\prime}$-CCC GCA ATC ACC ACC TGT CAC CA-3'. Both primers and probes were purchased from PE Applied Biosystems, as were the primers and probes for $\beta$-actin, which was used as endogenous control gene.

\section{Real-time PCR}

The reactions were performed in the ABI Prism 7700 Sequence Detection System (PE Applied Biosystems). The design of the TaqMan probes, combined with the $5^{\prime}-3^{\prime}$ nuclease activity of AmpliTaq Gold DNA polymerase (PE Applied Biosystems), allows the direct detection of the PCR product by the release of a fluorescent reporter during the PCR.

\section{PCR conditions}

cDNA $(3 \mu \mathrm{l})$ was added to the reaction mixture, which had a total volume of $25 \mu \mathrm{l}$. With the TaqMan PCR core reagent kit (PE Applied Biosystems) the concentrations used were as follows: $1 \times$ TaqMan buffer A, $5.0 \mathrm{~mm} \mathrm{MgCl}_{2}, 0.1 \mathrm{~mm}$ deoxynucleotide triphosphates, $0.1 \mu \mathrm{m}$ each of forward and reversed primers, $0.1 \mu \mathrm{M}$ probe, and 0.025 units $\mu \mathrm{l}^{-1}$ AmpliTaq Gold DNA polymerase. The thermal conditions used were $95^{\circ} \mathrm{C}$ for $10 \mathrm{~min}, 95^{\circ} \mathrm{C}$ for $15 \mathrm{~s}$ and $60^{\circ} \mathrm{C}$ for $1 \mathrm{~min}$. Steps two and three were repeated for 40 cycles. When we used the synthesised cDNA for each tumour, the $17 \beta$ HSD types 1 and 2 and $\beta$-actin specific sequences were amplified independently in separate reaction wells in triplicate. On the same plate, we included samples for standard curves for the target genes.

\section{Standard curve method}

A relative kinetic method was applied, using a standard curve, which was constructed with four-fold serial dilutions of cDNA from normal breast tissue. Standard curves were produced for the three target genes after each run. The target messages in unknown samples were quantified, using the standard curves, to determine a relative measure of the starting amount. The measures were normalised, which means that the level of 1 represents the expression level in normal mammary tissue.

\section{Statistical analysis}

The relationships between grouped variables were analysed with the $\chi^{2}$ test. Survival curves were produced according to the lifetable method described by Kaplan and Meier. Differences in recurrence-free survival were estimated with the log-rank test. Multivariate analysis of recurrence and mortality rates was performed with Cox proportional hazard regression. All the procedures are comprised in the statistical package STATISTICA 6.0 (StatSoft Scandinavia AB, Sweden). The criterion for statistical significance was $P<0.05$.

\section{RESULTS}

The 17HSD type 1 enzyme was detected in all of the 230 tumours analysed with a mean value of 2.3 . The tenth and the ninetieth percentile for $17 \beta$-HSD type 1 were 0.1 and 8.2 , respectively. To discriminate between low/intermediate and high expression of 17 HSD type 1 , the material was divided into two groups according to the mean level; lower $(<2.3)$, and higher $(>2.3)$. 17 $\beta$ Hydroxysteroid dehydrogenase type 2 mRNA was detected in $69 \%$ of the tumours. The tenth and ninetieth percentile for 17HSD type 2 were 0.0 and 0.92 , respectively. The mean expression level for 17HSD type 2 was 0.28 . To categorise the patients into two groups the mean value was used as cutoff. Since 17HSD types 1 and 2 cooperate to regulate the levels of E2 and E1, we also determined the ratio between these enzymes in each tumour. The majority showed low ratios as compared to normal. Using the upper tertile as cutoff level, we divided the material into groups with higher $(>0.2)$ or lower $(<0.2)$ ratios. The expression of 17HSD types 1 
and 2 were not significantly associated with other tumour characteristics, such as lymph node status, tumour size, ER status or PgR status (Table 1).

Table I 17 $\beta$-Hydroxysteroid dehydrogenase (I7HSD) types I and 2 expression and the $17 \mathrm{HSD} 2 / 17 \mathrm{HSD} \mid$ ratio in relation to tumour characteristics and tamoxifen treatment

\begin{tabular}{|c|c|c|c|c|c|c|}
\hline & \multicolumn{2}{|c|}{ |7HSD | } & \multicolumn{2}{|c|}{ I7HSD2 } & \multicolumn{2}{|c|}{ HSD2/HSDI } \\
\hline & $\begin{array}{c}<2.3 \\
n=|7|\end{array}$ & $\begin{array}{c}>2.3 \\
n=59\end{array}$ & $\begin{array}{r}<0.28 \\
n=175\end{array}$ & $\begin{array}{l}>0.28 \\
n=55\end{array}$ & $\begin{array}{c}<0.2 \\
n=154\end{array}$ & $\begin{array}{l}>0.2 \\
n=76\end{array}$ \\
\hline Lymphnode sta & & & & & & \\
\hline $\begin{array}{l}\mathrm{N}-,>20 \\
\mathrm{~N}+, \leqslant 20 \\
\mathrm{~N}+,<20\end{array}$ & $\begin{array}{l}48(75) \\
50(72) \\
68(77)\end{array}$ & $\begin{array}{l}16(25) \\
19(28) \\
20(23)\end{array}$ & $\begin{array}{l}47(73) \\
55(80) \\
66(75)\end{array}$ & $\begin{array}{l}17(27) \\
14(20) \\
22(25)\end{array}$ & $\begin{array}{l}39(61) \\
53(77) \\
54(61)\end{array}$ & $\begin{array}{l}25(39) \\
16(23) \\
34(39)\end{array}$ \\
\hline $\begin{array}{l}\text { ER- } \\
\text { ER+ }\end{array}$ & $\begin{array}{r}36(7 \mid) \\
135(75)\end{array}$ & $\begin{array}{l}15(29) \\
44(25)\end{array}$ & $\begin{array}{r}42(82) \\
133(74)\end{array}$ & $\begin{array}{r}9(18) \\
46(26)\end{array}$ & $\begin{array}{r}36(71) \\
118(66)\end{array}$ & $\begin{array}{l}15(29) \\
61(34)\end{array}$ \\
\hline $\begin{array}{c}\text { PgR status } \\
\text { PR- } \\
\text { PR+ }\end{array}$ & $\begin{array}{r}67(73) \\
104(75)\end{array}$ & $\begin{array}{l}25(27) \\
34(25)\end{array}$ & $\begin{array}{r}73(79) \\
102(74)\end{array}$ & $\begin{array}{l}19(21) \\
36(26)\end{array}$ & $\begin{array}{l}65(7 I) \\
89(64)\end{array}$ & $\begin{array}{l}27(29) \\
49(36)\end{array}$ \\
\hline $\begin{array}{l}\text { Tamoxifen } \\
\text { TAM } 2 \text { years } \\
\text { TAM } 5 \text { years }\end{array}$ & $\begin{array}{l}74(64) \\
97(84)\end{array}$ & $\begin{array}{l}41(36) \\
18(16)\end{array}$ & $\begin{array}{l}81(70) \\
94(82)\end{array}$ & $\begin{array}{l}34(30) \\
21(18)\end{array}$ & $\begin{array}{l}76(66) \\
78(68)\end{array}$ & $\begin{array}{l}39(34) \\
37(32)\end{array}$ \\
\hline
\end{tabular}
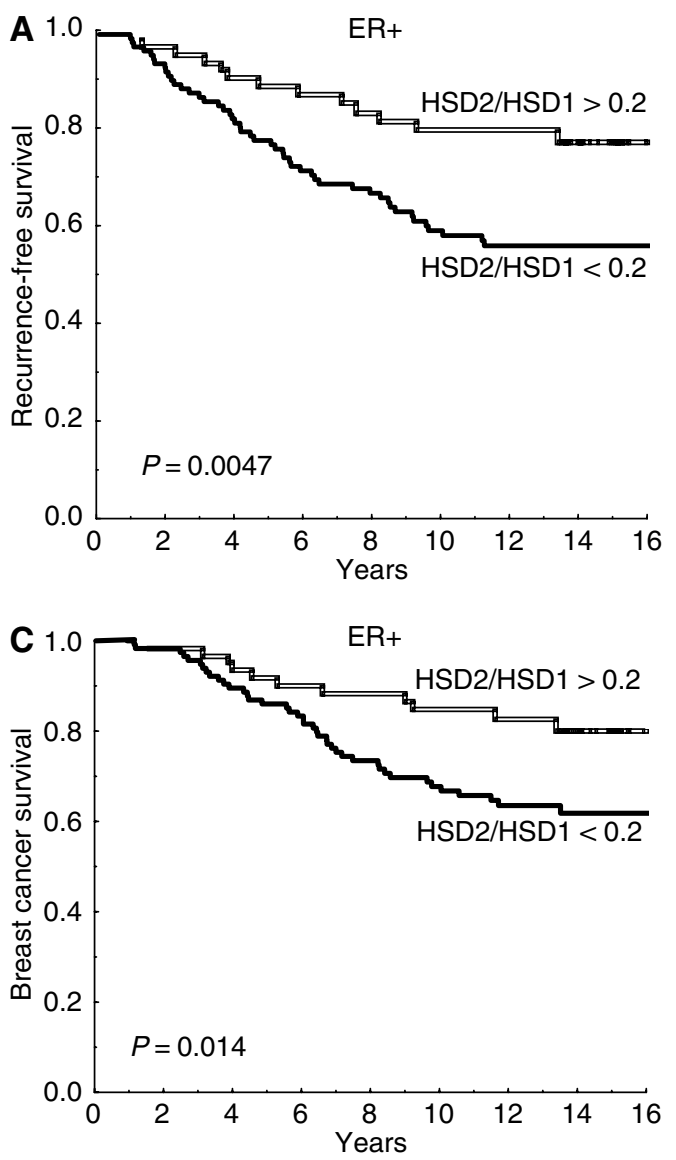

\section{Prognostic value of $17 \mathrm{HSD}$}

Oestrogen receptor-positive patients whose tumour had a high ratio (17HSD2/17HSD1 $>0.2$ ) showed a significantly better prognosis than patients with low ratios $(P=0.0047)$, whereas no association was found among ER negative patients $(P=0.34)$ (Figure 1). This stayed true in multivariate analysis, with regard to recurrence-free survival as well as breast cancer-specific survival (Table 2). A similar result was found for 17HSD type 2 alone. Among ER-positive patients, those with low expression of type 2 had a significantly higher recurrence rate compared with patients who expressed normal levels $(P=0.026)$ (Figure 2). This difference could not be seen among ER-negative patients $(P=0.62)$. The prognostic significance of type 2 hold true in multivariate analysis $(P=0.042)$. There was no significant association between 17HSD type 1 and recurrence-free survival if the entire follow-up period was considered (Figure 3A). However, for ER positive patients still recurrence-free after 5 years, high levels of 17HSD type 1 was associated with a significantly higher rate of late relapse in the disease $(P=0.0051)$ (Figure $3 \mathrm{~B})$.

\section{Expression of 17HSD and benefit of $5 v s 2$ years tamoxifen treatment}

Oestrogen receptor-positive patients with low 17HSD2/17HSD1 ratios tended to have the advantage of 5 instead of 2 years tamoxifen treatment ( 5 vs 2 years recurrence rate ratio, $\mathrm{RR}=0.56$, 95\% CI, $0.29-1.06, P=0.072$ ). This difference could not be seen among patients with high ratios $(\mathrm{RR}=0.92(0.28-3.0), P=0.90)$. The same pattern was observed for 17HSD type 2 alone, that is, ERpositive patients with low expression benefited from prolonged
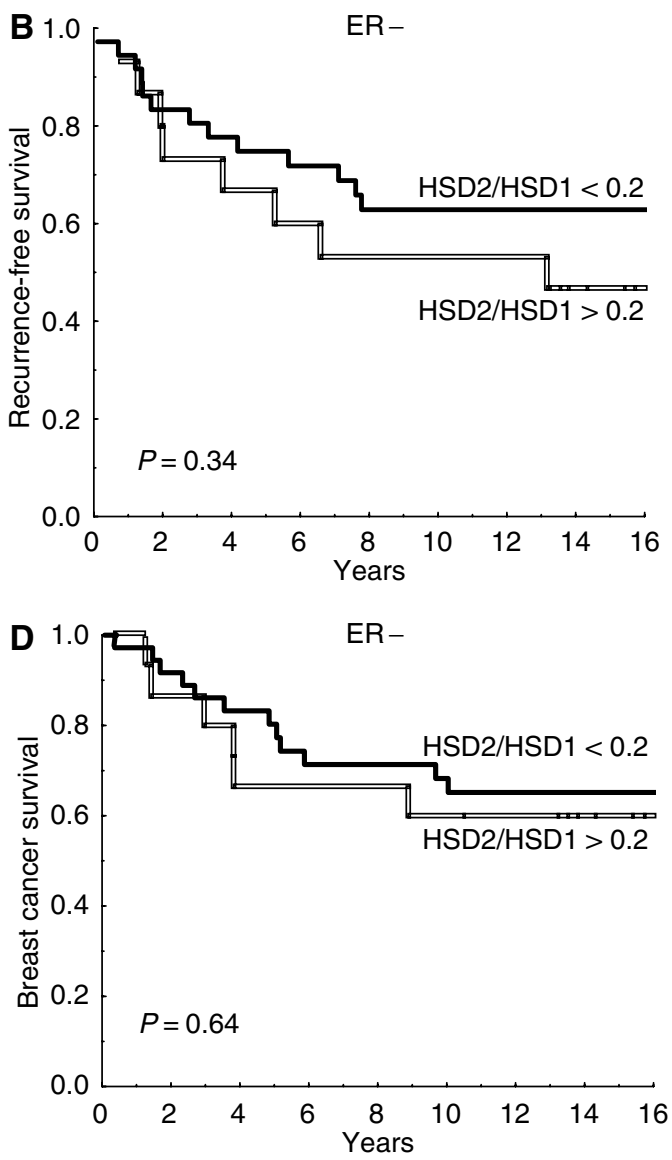

Figure I Recurrence-free survival (A, B) and breast cancer survival $(\mathbf{C}, \mathbf{D})$ in relation to the ratio of I $7 \beta$-hydroxysteroid dehydrogenase (I7HSD) type 2 and type I mRNA expression (I 7HSD2/I7HSDI). $(\mathbf{A}, \mathbf{C})$ oestrogen receptor-positive $(E R+)$ patients $(n=\mid 79)$ and $(\mathbf{B}, \mathbf{D})$ ER negative patients $(n=5 \mathrm{I})$. 
Table 2 Multivariate analysis (Cox) of recurrence rate ratio and breast cancer mortality rate ratio for oestrogen receptor (ER)-positive patients in relation to I7 $\beta$-hydroxysteroid dehydrogenase (I7HSD) types I and 2 and other variables

\begin{tabular}{|c|c|c|c|c|}
\hline & \multicolumn{2}{|c|}{ Recurrence } & \multicolumn{2}{|c|}{ Breast cancer mortality } \\
\hline & $\operatorname{RR}(95 \% \mathrm{Cl})$ & Significance & $\mathbf{R R}(95 \% \mathbf{C l})$ & Significance \\
\hline \multicolumn{5}{|c|}{ HSD2/HSDI } \\
\hline$\leqslant 0.2$ & 1.0 & & 1.0 & \\
\hline$>0.2$ & $0.43(0.23-0.80)$ & $P=0.0083$ & $0.43(0.22-0.85)$ & $P=0.015$ \\
\hline \multicolumn{5}{|c|}{ Nodal status } \\
\hline $\mathrm{N}-$ & 1.0 & & 1.0 & \\
\hline $\mathrm{N}+$ & $2.2(1.09-4.3)$ & $P=0.027$ & $2.6(1.2-5.5)$ & $P=0.012$ \\
\hline \multicolumn{5}{|c|}{ Tumour size (mm) } \\
\hline$\leqslant 20$ & 1.0 & & 1.0 & \\
\hline$>20$ & $1.5(0.83-2.7)$ & $P=0.18$ & $2.1(1.08-4.2)$ & $P=0.030$ \\
\hline \multicolumn{5}{|l|}{ PgR status } \\
\hline PgR- & $\begin{array}{r}1.0 \\
072.0\end{array}$ & & 1.0 & \\
\hline PgR+ & $0.72(0.42-1.2)$ & $P=0.24$ & $0.73(0.4 \mid-1.3)$ & $P=0.30$ \\
\hline \multicolumn{5}{|l|}{ Tamoxifen } \\
\hline 2 years & 1.0 & & 1.0 & \\
\hline 5 years & $0.75(0.45-1.25)$ & $P=0.27$ & $0.99(0.57-1.7)$ & $P=0.98$ \\
\hline
\end{tabular}

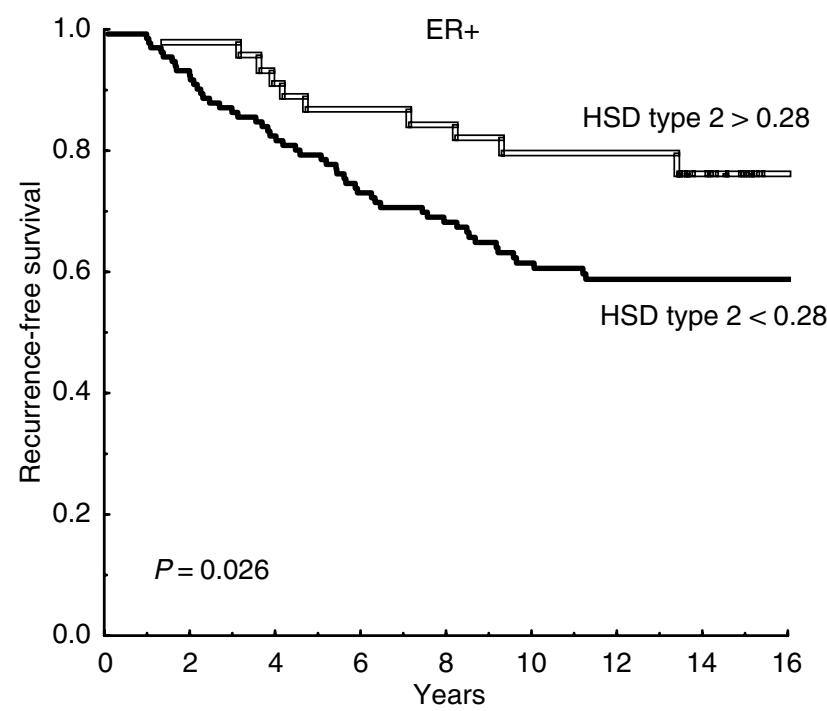

Figure 2 Recurrence-free survival for oestrogen receptor-positive patients with decreased $(<0.28)$ and normal $(>0.28)$ expression of $17 \beta$-hydroxysteroid dehydrogenase (HSD) type 2 mRNA $(n=133$ and $n=46$, respectively).

treatment, whereas those showing higher type 2 levels appeared to have similar recurrence-free survival with 2 and 5 years of treatment (5 vs 2 years, $\mathrm{RR}=0.60(95 \% \mathrm{CI}, 0.35-1.04)$ and $\mathrm{RR}=1.01(0.28-3.6)$, respectively). Oestrogen receptor-positive patients with lower levels of 17HSD type 1 showed a $40 \%$ reduced risk of recurrence with prolonged treatment $(\mathrm{RR}=0.60(0.33-$ 1.09)), whereas a benefit from prolonged treatment was not evident for those with increased type $1(R R=1.33(0.52-3.4))$. However, the difference between the groups was not statistically significant.

\section{DISCUSSION}

For ER positive patients in this study, the 17HSD2/17HSD1 ratio had a prognostic significance. A higher 17HSD2/17HSD1 ratio
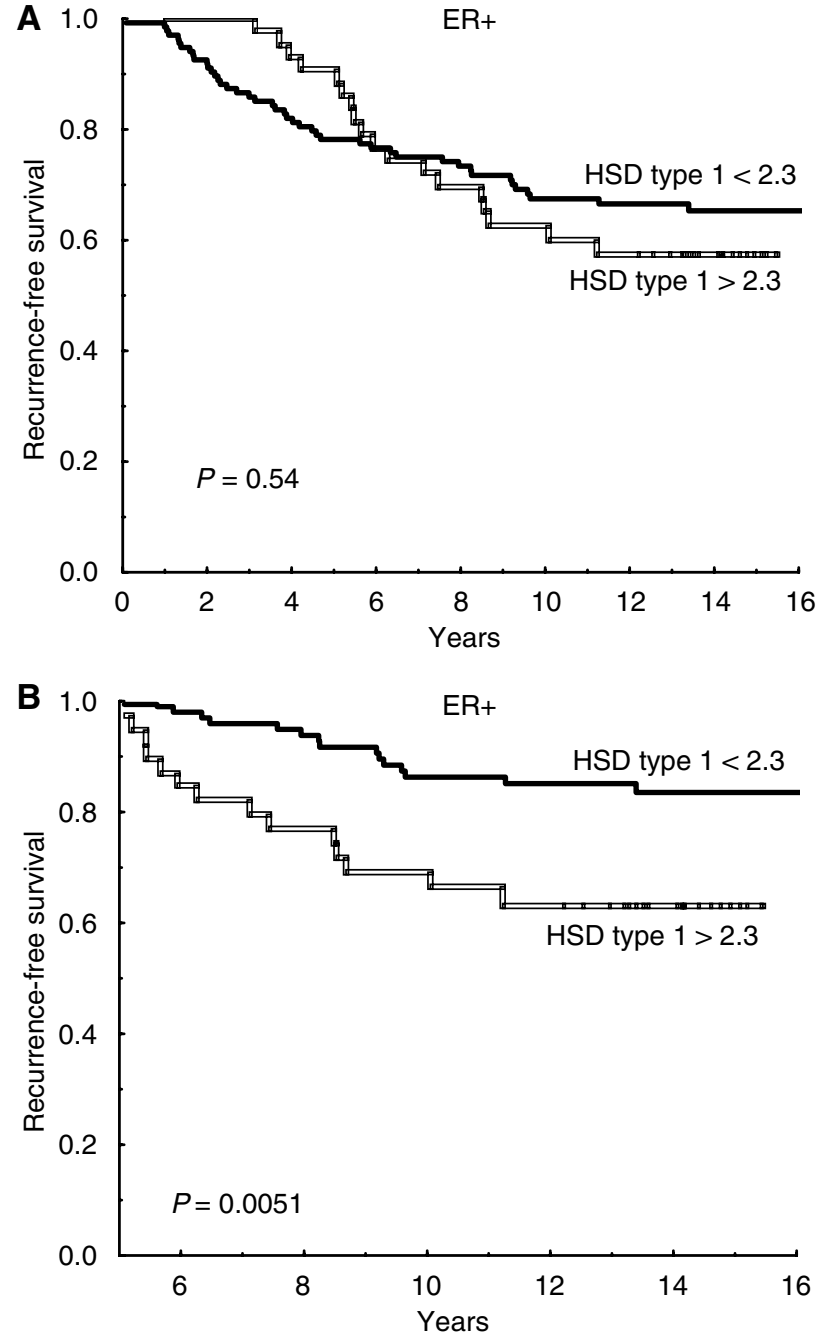

Figure 3 Recurrence-free survival for oestrogen receptor-positive patients with low/normal $(<2.3)$ and increased $(>2.3)$ expression of 17 $\beta$-hydroxysteroid dehydrogenase (HSD) type I mRNA ( $n=135$ and $n=44$, respectively). The entire follow-up period is shown in $(\mathbf{A})$. Patients still recurrence-free after 5 years were analysed for later events and their outcome is shown in (B)

gives an increased oxidative activity $(\mathrm{E} 2 \rightarrow \mathrm{E} 1)$, and in the present study, this was associated with a good prognosis. In contrast, a low ratio leads to increased reductive activity $(\mathrm{E} 1 \rightarrow \mathrm{E} 2)$. Irrespective of E1 production, as a result of aromatase or steroid sulphatase activity, 17HSD types 1 and 2 are responsible for the balance of E1 and E2. It has previously been shown that in normal breast tissue the oxidative pathway $(\mathrm{E} 2 \rightarrow \mathrm{E} 1)$ dominates, whereas in malignant breast tumours the reductive pathway $(\mathrm{E} 1 \rightarrow \mathrm{E} 2)$ is dominant (Speirs et al, 1998). These results suggest that intratumoral regulation of oestradiol levels is of importance.

Other enzymes involved in oestrogen synthesis may have prognostic significance, and Utsumi and colleagues (1999) suggested steroid sulphatase as a useful marker for identification of high-risk breast cancer patients. Miyoshi et al (2001) observed that intratumoral E2 levels are not significantly different between premenopausal and postmenopausal patients and the authors suggested that upregulation of 17HSD type 1 is important in the maintenance of high intratumoral E2 levels especially in postmenopausal patients. In a more recent study, Miyoshi et al (2003) demonstrated that the intratumoral sulphatase mRNA levels, but not the aromatase and $17 \beta$-HSD1 mRNA levels, have prognostic 
value in ER-positive breast cancer patients. In the same study, patients with high levels of 17HSD type 1 tended to have a worse prognosis than those with low levels.

The gene encoding 17HSD type 1 is located at $17 q 12-21$, a region that often is rearranged in breast cancer (Plummer et al, 1997, Kauraniemi et al, 2001). In a recent study, we found amplification of the gene encoding 17HSD type 1 in $14.5 \%$ of the breast tumours (Gunnarsson et al, 2003).

In the present study, we found that a high expression of 17HSD type 1 predicted late recurrence among ER-positive patients and apparently decreased benefit from prolonged tamoxifen treatment. This could indicate that tamoxifen does not completely block the action of E2 in some patients due to high levels of E2. Acquired tamoxifen resistance is believed to arise due to increased phosphorylation of the ER by growth factor signalling or due to increased expression of coactivators (Nicholson et al, 2004, Schiff et al, 2004). This means that tamoxifen acts as an agonist after long duration of treatment in some patients, and the question is how the resistant tumour cells will respond to high E2 levels after the completion of tamoxifen treatment. It has previously been shown that tamoxifen treatment for longer periods than 5 years is not preferable (Fisher et al, 2001). A recent study pointed out aromatase inhibitor as significantly more efficient than placebo among postmenopausal women after 5 years tamoxifen treatment (Goss et al, 2003). Some ER-positive patients with metastatic disease who have failed on tamoxifen treatment still show response to aromatase inhibitors (Dowsett, 1997). In particular, for patients with high intratumoral E2 levels the switch to aromatase inhibitor after some period of tamoxifen treatment could be favourable.

Suzuki et al (2000) observed that 17HSD type 1 was immunolocalised in carcinoma cells in a majority of invasive ductal carcinomas, while 17HSD type 2 was not detected in any of the cases. The authors suggested that type 1 is the enzyme of interest in breast cancer. In a previous case/control study, we found that a low or undetectable level of type 2 as well as a high expression of type 1 was associated with a worse prognosis in breast cancer (Gunnarsson et al, 2001). The results in the present study are in line with the previous study; however, the present series is larger and not selected as in the case/control study. Among ER positive patients in the present study there was a significant difference in prognosis in relation to 17HSD type 2. Patients who had a low or undetectable level of type 2 had a

\section{REFERENCES}

Cleton-Jansen AM, Callen DF, Seshadri R, Goldup S, Mccallum B, Crawford J, Powell JA, Settasatian C, van Beerendonk H, Moerland EW, Smit VT, Harris WH, Millis R, Morgan NV, Barnes D, Mathew CG, Cornelisse CJ (2001) Loss of heterozygosity mapping at chromosome arm 16q in 712 breast tumours reveals factors that influence delineation of candidate regions. Cancer Res 61: 1171-1177

Dowsett M (1997) Future uses for aromatase inhibitors in breast cancer. J Steroid Biochem Mol Biol 61: 261 - 266

Elo JP, Harkonen P, Kyllonen AP, Lukkarinen O, Poutanen M, Vihko R, Vihko P (1997) Loss of heterozygosity at 16q24.1-q24.2 is significantly associated with metastatic and aggressive behavior of prostate cancer. Cancer Res 57: 3356-3359

English M, Stewart PM, Hewison M (2001) Estrogen metabolism and malignancy: analysis of the expression and function of $17 \beta$-hydroxysteroid dehydrogenases in colonic cancer. Mol Cell Endocrinol 171: 53-60

Fisher B, Dignam J, Bryant J, Wolmark N (2001) Five versus more than five years of tamoxifen for lymph node-negative breast cancer: updated findings from the nation surgical adjuvant breast and bowel project B-14 randomized trial. J Natl Cancer Inst 93: 684-690

Goss PE, Ingle JN, Martino S, Robert NJ, Muss HB, Piccart MJ, Castiglione M, Tu D, Shepherd LE, Pritchard KI, Livingston RB, Davidson NE, Norton L, Perez EA, Abrams JS, Therasse P, Palmer MJ, Pater JL (2003) A randomized trial of letrozole in postmenopausal women after five years significantly higher risk of recurrence. These results stayed true in multivariate analysis including other prognostic factors. The loss of 17HSD type 2 expression could result in a significant increase of the more biologically active E2. It has been shown in colon cancer that loss of type 2 is an early event in cancer development, and the authors suggested that type 2 protects the colonic mucosa from E2 (English et al, 2001). In a more recent study, Oduwole et al suggest that low expression of 17HSD type 2 in colon cancer is an independent marker of favourable prognosis in females. The female patients with high expression of type 2 had a poor prognosis and often tumours with a mucinous component (Oduwole et al, 2003).

The gene encoding 17HSD type 2 is located at 16q24 and loss of heterozygosity ( $\mathrm{LOH})$ at this site is a frequent and early event in breast cancer (Cleton-Jansen et al, 2001). Moreover, in prostate cancer, LOH at $16 \mathrm{q}$ is common, and Elo et al (1997) discussed whether activity of 17HSD type 2 protects prostatic epithelial cells from excessive androgen action and reduces the proliferative pressure on prostatic cells. Significantly decreased mRNA expression of 17HSD type 2 in prostate cancer as compared to normal prostate tissue has also been reported (Koh et al, 2002). In the future, it would be of interest to see if the high frequency of $\mathrm{LOH}$ at $16 \mathrm{q} 24$ in breast cancer includes the gene coding for 17HSD type 2.

We found that 17HSD type 2 was expressed in the normal mammary gland, whereas the expression levels were low or undetectable in a majority of ER positive breast neoplasms. We also found a favourable prognosis among patients with ER positive tumours that expressed higher mRNA levels of the enzyme. As the loss of 17HSD type 2 activity results in an increased reductive activity $(\mathrm{E} 1 \rightarrow \mathrm{E} 2)$, this might be an important mechanism in the pathogenesis of ER-positive breast cancer. Previous studies have shown most interest in 17HSD type 1. This study indicates that 17HSD type 2 and the 17HSD2/17HSD1 ratio may be even more important, which motivates further investigations.

\section{ACKNOWLEDGEMENTS}

This work was supported by grants from the Swedish Cancer Society of tamoxifen therapy for early-stage breast cancer. $N$ Engl J Med 349: $1793-1802$

Gunnarsson C, Ahnstrom M, Kirschner K, Olsson B, Nordenskjold B, Rutqvist LE, Skoog L, Stål O (2003) Amplification of HSD17B1 and ERBB2 in primary breast cancer. Oncogene 22: $34-40$

Gunnarsson C, Olsson B, Stål O, Members of the Southeast Sweden Breast Cancer Group (2001) Abnormal expression of $17 \beta$-hydroxysteroid dehydrogenases in breast cancer predicts late recurrence. Cancer Res 61: $8448-8451$

Kauraniemi P, Barlund M, Monni O, Kallioniemi A (2001) New amplified and highly expressed genes discovered in the ERBB2 amplicon in breast cancer by cDNA microarrays. Cancer Res 61: 8235-8240

Koh E, Noda T, Kanaya J, Namiki M (2002) Differential expression of $17 \beta$ hydroxysteroid dehydrogenase isozyme genes in prostate cancer and noncancer tissue. Prostate 53: 154-159

Miettinen MM, Mustonen MV, Poutanen MH, Isomaa VV, Vihko RK (1996) Human $17 \beta$-hydroxysteroid dehydrogenase type 1 and type 2 isoenzymes have opposite activities in cultured cells and characteristic cell and tissue-specific expression. J Biochem 314: 839-845

Miettinen M, Mustonen M, Poutanen M, Isomaa V, Wickman M, Soderqvist G, Vihko R, Vihko P (1999) 17 $\beta$-hydroxysteroid dehydrogenases in normal human mammary epithelial cells and breast tissue. Breast Cancer Res Treat 57: $175-182$ 
Miyoshi Y, Ando A, Hasegawa S, Ishitobi M, Taguchi T, Tamaki Y, Noguchi S. (2003) High expression of steroid sulfatase mRNA predicts poor prognosis in patients with estrogen receptor-positive breast cancer. Clin Cancer Res 9: 2288-2293

Miyoshi Y, Ando A, Shiba E, Taguchi T, Tamaki Y, Noguchi S (2001) Involvement of up-regulation of $17 \beta$-hydroxysteroid dehydrogenase type 1 in maintenance of intratumoral high estradiol levels in postmenopausal breast cancers. Int J Cancer 94: 685-689

Nicholson RI, Hutcheson IR, Knowlden JM, Jones HE, Harper ME, Jordan N, Hiscox SE, Barrow D, Gee JMW (2004) Nonendocrine pathways and endocrine resistance: Observations with antiestrogens and signal transduction inhibitors in combination. Clin Cancer Res 10: $346-354$

Oduwole OO, Makinen MJ, Isomaa VV, Pulkka A, Jernvall P, Karttunen TJ, Vihko PT (2003) 17 $\beta$-hydroxysteroid dehydrogenase type 2: independent prognostic significance and evidence of estrogen protection in female patients with colon cancer. J Steroid Biochem Mol Biol 87: $133-140$

Peltoketo H, Luu-The V, Simard J, Adamski J (1999) 17beta-hydroxysteroid dehydrogenase (HSD)/17-ketosteroid reductase (KSR) family; nomenclature and main characteristics of the $17 \mathrm{HSD} / \mathrm{KSR}$ enzymes. $\mathrm{J} \mathrm{Mol}$ Endocrinol 23: 1-11

Plummer SJ, Paris MJ, Myles J, Tubbs R, Crowe J, Casey G (1997) Four regions of allelic imbalance on 17q12-qter associated with high-grade breast tumours. Genes Chromosomes Cancer 20: 354-362

Poutanen M, Isomaa V, Lehto VP, Vihko (1992) Immunological analysis of $17 \beta$-hydroxysteroid dehydrogenase in benign and malignant human breast tissue. Int J Cancer 50: 386-390

Purohit A, Newman SP, Reed MJ (2002) The role of cytokines in regulating estrogen synthesis: implications for the etiology of breast cancer. Breast Cancer Res 4: 65-69
Sasano H, Frost AR, Saitoh R, Harada N, Poutanen M, Vihko R, Bulun SE, Silverberg SG, Nagura H (1996) Aromatase and $17 \beta$-hydroxysteroid dehydrogenase type 1 in human breast carcinoma. J Clin Endocrinol Metab 11: $4042-4046$

Schiff R, Massarweh SA, Shou J, Bharwani L, Mohsin SK, Osborne CK (2004) Cross-talk between estrogen receptor and growth factor pathways as a molecular target for overcoming endocrine resistance. Clin Cancer Res 10: $331-336$

Speirs V, Green AR, Atkin S (1998) Activity and gene expression of $17 \beta$ hydroxysteroid dehydrogenase type 1 in primary cultures of epithelial and stromal cells derived from normal and tumourous human breast tissue: the role of IL-8. J Steroid Biochem Mol Biol 67: 267-274

Speirs V, Walton DS, Hall MC, Atkin SL (1999) In vivo and in vitro expression of steroid-converting enzymes in human breast tumours: associations with interleukin-6. Br J Cancer 81: 690-695

Suzuki T, Moriya T, Ariga N, Kaneko C, Kanazawa M, Sasano H (2000) $17 \beta$ Hydroxysteroid dehydrogenase type 1 and type 2 in human breast carcinoma: a correlation to clinicopathological parameters. Br J Cancer 82: $518-523$

Swedish Breast Cancer Cooperative Group (1996) Randomized trial of two versus five years of adjuvant tamoxifen for postmenopausal early stage breast cancer. J Natl Cancer Inst 88: 1543 - 1549

Utsumi T, Yoshimura N, Takeuchi S, Ando J, Maruta M, Maeda K, Harada N (1999) Steroid sulfatase expression is an independent predictor of recurrence in human breast cancer. Cancer Res 59: 377-381

Vihko P, Isomaa V, Ghosh D (2001) Structure and function of $17 \beta$ hydroxysteroid dehydrogenase type 1 and 2. Mol Cell Endocrinol 171: $71-76$

Yue W, Wang JP, Hamilton CJ, Demers LM, Santen RJ (1998) In situ aromatization enhances breast tumor estradiol levels and cellular proliferation. Cancer Res 58: 927-932 